\title{
DUALITY, URBANIZATION, AND MODERNIZATION OF AGRIFOOD SYSTEMS IN LATIN AMERICA AND THE CARIBBEAN
}

\author{
Eugenio Díaz-Bonilla and Ruben G. Echeverría
}

The agriculture sector in Latin America and the Caribbean (LAC) is certainly not homogeneous, covering a variety of very different agroecological and climate zones, along a south-north axis. ${ }^{1}$ There are three large agricultural producers: Brazil (close to 48 percent of total agricultural production in the region on average during the 2010s), Argentina (almost 14 percent), and Mexico (about 12 percent), along with several intermediate and small producers, which, added together, have as much agricultural production as Argentina and Mexico combined.

Within that diversity, it is possible to identify three broad agricultural situations, a product of geography and climate, the historical occupation of space during the period of discovery and settlement of the Americas, and the different cycles of integration in global markets. A first group (exemplified by Brazil) was based on tropical agriculture for exports, which started with sugar produced in large plantations with slave labor in the 1600s and then expanded to other crops such as coffee, cocoa, tobacco, and bananas, eventually moving to salaried work in modern times.

A second group (which includes Mexico and Peru) was based on local staple crops (such as corn and potatoes) and livestock production oriented to local markets in economies dominated by mineral production for exports (gold and silver originally, but later other products such as copper, tin, and oil). In this second group, during colonial times land was also occupied in large productive units that used indentured labor from indigenous communities,

1 Latin America and the Caribbean comprises 33 nations according to the United Nations. Listed in alphabetical order they are Antigua and Barbuda, Argentina, Bahamas, Barbados, Belize, Bolivia, Brazil, Chile, Colombia, Costa Rica, Cuba, Dominica, Dominican Republic, Ecuador, El Salvador, Grenada, Guatemala, Guyana, Haiti, Honduras, Jamaica, Mexico, Nicaragua, Panama, Paraguay, Peru, Saint Kitts and Nevis, Saint Lucia, Saint Vincent and the Grenadines, Suriname, Trinidad and Tobago, Uruguay, and Venezuela. The region also has 15 territories that are dependencies of other countries, of which Puerto Rico is the largest. Here we refer to the 33 nations. 
who were allowed to produce for self-consumption in smaller plots. Over time, these large units also moved toward more commercial operations based on salaried work.

The third group has been the temperate-climate agriculture on the southern plains of South America (basically Argentina and Uruguay). Lacking minerals and the possibility of producing highly priced tropical products, these regions attracted far less migration during colonial times. Agricultural activities started with extensive livestock production in large production units (given the low population density), which, following changes in world demand, eventually evolved to grain production and more specialized livestock activities toward the end of the 19th century and beginning of the 20th century. But by then, the land had already been occupied in large tracts, and landowners started to rent the land to sharecroppers for agriculture.

In the end, all three types of agriculture generated a dichotomy between a small number of large establishments ("latifundios") and a large number of small ones ("minifundios"), the traditional LAC dual agrarian structure.

Another characteristic of agriculture in LAC is that since the region got integrated into world markets during colonial times, the evolution of the global economy determined to a large extent the performance of the agriculture sector. This has obviously been the case for countries with agriculture sectors oriented to export markets since colonial times, where the cycles of demand for and supply of their products in the world economy shaped the overall functioning of the countries' economies. But also in the case of those countries whose economies were based on exports of mineral products and oil, their agriculture sector was heavily influenced by global developments in those other primary products through their impacts on exchange rates and international trade, public revenues and expenditures, and the influence on the evolution of aggregate domestic demand.

With those two characteristics in mind (inequality in land structures and the strong influence of global markets), this chapter will look at the evolution of the agrifood system and related policies in LAC during the last decades.

2 The unequal agrarian structures in all three types of agricultural groups (very different from the more egalitarian occupation of land by family farms in the United States and Canada) have affected, although to different degrees depending on the countries, the development of both democracy and broad-based domestic markets (Engerman and Sokoloff 2002). 


\section{Changing Roles of Agriculture}

The role of the agricultural sector and related policies must be considered in the context of the whole economy, with four levels of analysis: farmers (supply side), the performance of the whole economy and opportunities for trade (demand side), the links between supply and demand through value chains, and the geographical setting where those activities take place. From a geographical point of view, farmers are part of a rural and regional economy. From an economic point of view, they are part of agricultural value chains. These levels are embedded in the general economy, which determines the overall governance and policy setting, as well as the final demand for agricultural products in both domestic and external markets (Díaz-Bonilla 2015).

In LAC, as in other developing countries, a key policy issue has been the balance between the agriculture sector vis-à-vis other productive sectors in their economic strategies. A related aspect has been how LAC policies approached the traditional food policy dilemma of trying to maintain high prices for agricultural producers or keeping them low for consumers, with its impact also on the economic and social balance between rural areas and urban centers.

Another policy dilemma in LAC, resulting from its unequal agrarian structure, has been whether to pursue growth and production prioritizing larger agricultural units or to emphasize poverty reduction and food security with a focus on small farmers. ${ }^{3}$ As briefly discussed immediately, there have been different policy approaches to the triple dichotomy (agriculture versus other sectors, rural versus urban, and large versus small producers).

After World War II many countries in LAC followed policies that considered the role of agriculture to be subordinate to the needs of industrialization and of the urban population, in what was called the "import substitution industrialization" (ISI) strategy. Economic arguments in favor of industrialization included the idea of declining terms of trade of countries exporting agricultural products (or primary products, in general) compared with those exporting industrial goods (Singer 1950; Prebisch 1950, 1968).

Within the context of the ISI strategy, agricultural policies were based mostly on the use of administered prices at different stages of the market chain, the existence of public and parastatal enterprises operating in product and input markets, and the establishment of public agricultural banks to

3 There are several studies arguing the positive impacts of an agrarian structure based on family farms on the emergence of democratic governance and on the formation of larger domestic markets that support the development of industry and other activities (Engerman and Sokoloff 2002). 
supply subsidized credit. By and large those policies tried to support "modern," large producers. The policies followed included the technological component embedded in the Green Revolution, which led to the creation of the national agricultural research institutes and extension services starting in the late 1950s. The challenge of poverty in rural areas was mainly addressed through community development and land or agrarian reform.

The economic crises of the 1980s led to a change of strategy in LAC, in line with different studies that argued that ISI was economically inefficient and led to high inflation and macroeconomic crises (Little, Scitovsky, and Scott 1970; Balassa 1971). Also, ISI was criticized because it discriminated against agriculture and negatively affected employment, income distribution, and poverty. Agricultural sectoral policies were negatively evaluated as well for what was considered a maze of inefficient and at times contradictory interventions, subsidies, and public enterprises operating on input and output markets.

During the 1980s and 1990s, there was a change in macroeconomic, trade, and sectoral policies in LAC that led to the reduction or elimination of industrial protection and of the overvaluation of the exchange rate, along with the phasing out of export taxes on agriculture and a substantial revamping and scaling down of government's involvement in agricultural markets (World Bank 1986). The idea was that given that incentives would shift in favor of agriculture with the change in the general macroeconomic and trade framework, then all those other sectoral public interventions trying to compensate the previous negative bias were not necessary. The poor, particularly in rural areas, were supposed to benefit from more sustainable growth once the capitalintensive and antiagricultural development strategy was corrected.

However, while price distortions were reduced or eliminated during the 1980 s and 1990s, other developments were moving against the agricultural sector in LAC. ${ }^{4}$ The 1980 s debt crisis led to a significant decline in growth in the region, dubbed "the lost decade," which hurt domestic demand for agricultural goods. Also, some of the reforms, while eliminating many of the inefficient and contradictory public-sector interventions, ended up, at the same

4 Anderson and Nelgen (2013) calculated the levels of support (or taxation) for the agriculture sector for several countries and regions at the world level. Those estimates calculate the support to producers that can come from the rest of the society as consumers (mainly through trade policies) or as taxpayers (through fiscal policies). By their estimates, LAC's overall and sectoral policies implied a tax on the agriculture sector of about 13 percent of the value of the production during the 1950 s and until the 1980 s (see also Chapter 13). After that, the authors calculate, the bias against agriculture changed into positive support for the sector in LAC, with a net subsidy equivalent to about 3.5 percent of the value of production on average during the period 1990-2010. 
time, dismantling the institutional infrastructure that provided technical assistance and some key inputs to agricultural production, without ensuring the creation of private-sector institutions that could provide similar services and inputs.

Additionally, there were two important changes in external conditions. First, particularly since the 1980s, the extensive support and protection of agriculture in rich countries led to surpluses that were sold in world markets with subsidies, depressing world prices. Second, expanded capital flows led to a more volatile economic environment for developing countries, with the sequence of crises in Mexico in 1995, Asia in 1997, Russia in 1998, Brazil in 1999, and Argentina in 2001, which had negative implications for world growth and agricultural demand.

In terms of poverty alleviation, in the second half of the 1990s a new type of poverty reduction program began to be implemented in LAC, such as Mexico's “Progresa," Brazil’s "Bolsa Scola," and similar programs. They basically consisted of income transfers given mostly to heads of households (many of them women), but with specific commitments related to attendance at school and health controls for their children. The programs appear to have had positive impacts on local economic activity and on accumulation of physical and human capital (Adato and Hoddinot 2010).

After the policy reforms in the 1980s and 1990s reduced, or even eliminated, the past bias in macro incentives against agriculture, the framework of incentives in LAC began to move, although with variations, in support of agriculture.

Table 6.1 shows nominal rates of protection (NPRs), which are the percentages by which the domestic prices paid by consumers and received by producers are above (or below) the equivalent world price. ${ }^{5}$

Table 6.1 shows that until the last year available (2015), Argentina was the only country in the region that placed domestic prices below those prevailing in world markets. A second group of countries maintained domestic prices broadly in line with world markets (between 0 and 10 percent). But other countries have tilted domestic prices in favor of agricultural producers and against domestic consumers (10 percent or more), with cases of NPRs of more than 30 percent (Jamaica, Haiti, and El Salvador), and even reaching 55.5 percent in the case of the Dominican Republic.

5 The measure reported in Table 6.1 represents mostly transfers from consumers, unlike the Anderson and Nelgen (2013) estimates, which also include transfers from taxpayers. The NPR numbers presented here are an aggregation of different products included in the database (details can be found at http://www.ag-incentives.org/). 
TABLE 6.1 Nominal rates of protection

\begin{tabular}{lclclccc}
\hline Country & $\begin{array}{c}\text { Above 20 } \\
(\%)\end{array}$ & Country & $\begin{array}{c}10-20 \\
(\%)\end{array}$ & Country & $\begin{array}{c}0-10 \\
(\%)\end{array}$ & Country & $\begin{array}{c}\text { Negative } \\
(\%)\end{array}$ \\
\hline Dominican Republic & 55.5 & Colombia & 18.7 & Ecuador & 6.2 & Argentina & -26.5 \\
Jamaica & 37.1 & Honduras & 17.5 & Peru & 4.5 & & \\
Haiti & 33.6 & Suriname & 13.8 & Mexico & 2.9 & \\
El Salvador & 32.1 & Nicaragua & 13.6 & Brazil & 2.2 & \\
Guatemala & 22.3 & Belize & 13.1 & Uruguay & 1.0 & \\
& & Bolivia & 13.1 & Chile & 0.6 & \\
& & Guyana & 12.5 & Paraguay & 0.0 & \\
& & Costa Rica & 10.3 & & & & \\
\hline
\end{tabular}

Source: Aglncentives (2020).

Note: The years of the calculations vary by country, but they are within the period 2005-2015.

The policy changes were accompanied by a rebound of growth in LAC's agricultural production during the last two decades (see Production, in the second section), which also transformed LAC into the main net exporter of agricultural products, as can be seen in Figure 6.1, with the region surpassing the United States, Canada, Australia, and New Zealand combined.

The net trade surplus has been generated mainly by Brazil and Argentina, with some contribution from the rest of LAC (where some countries are net importers).

The structure of agricultural trade for LAC also changed significantly during recent decades, with increases in exports of oilseeds and related meal and oil products and, to a smaller degree, fruits and vegetables. Other historically important products, such as sugar and coffee, have declining shares both in LAC's and the world's share of exports. Also to be noted is that the direction of trade (historically more directed to Europe and the United States) has become more diversified, with an increased presence of Asian markets, particularly China (see also Chapter 13$)^{6}{ }^{6}$

Since the price shocks of 2008 and 2011, several LAC countries seem to have reverted in part to greater involvement of the public sector in agriculture related to concerns about food security. However, the main malnutrition

6 In general, China has become the top destination for South American exports and the second destination for all of LAC exports, after the United States. However, the composition of LAC exports to China is heavily tilted toward primary commodities, much more than the overall composition of LAC exports to the world, while LAC is buying mostly manufacturing goods and running an important deficit with China. This has led to debates about the benefits for LAC of such structure of trade. 
FIGURE 6.1 Net agricultural trade (million current US dollars)

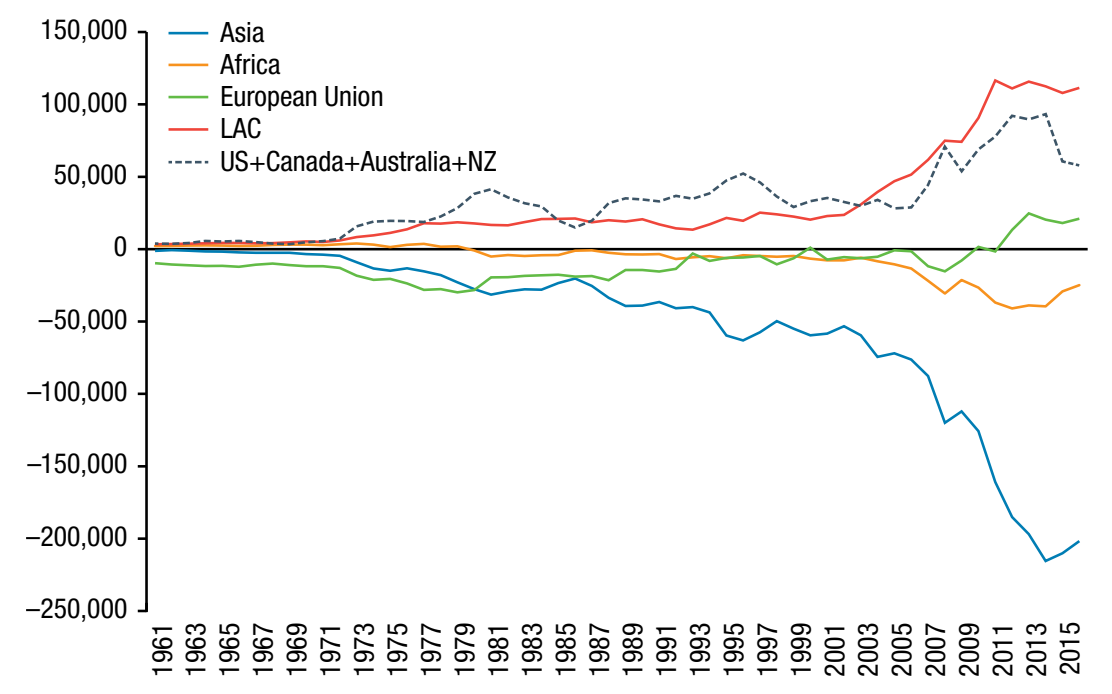

Source: Authors' calculation based on FAO (2018).

Note: $L A C=$ Latin America and the Caribbean. NZ = New Zealand.

problems in LAC are becoming less those of undernourishment and food insecurity, and more those of the two other burdens of malnutrition-deficiencies in different micronutrients and vitamins, and overweight and obesity (see Nutritional Transition, in the third section).

Part of these changes have been related to the emergence of LAC as the most urbanized developing region (Table 6.2): the percentage of urban population increased from 52 percent in the 1960s to almost 79 percent in the 2010s, way above the world's average of 53 percent (Díaz-Bonilla and Torero 2016).

It should be noted that although LAC has several megacities, almost 60 percent of the region's urban population is located in intermediate and small towns of less than 1 million inhabitants, as is shown in Table 6.2 (see also Chapter 9).

Therefore, the process of overall urbanization has been relatively more evident in the development of small and intermediate towns, which have stronger links to rural spaces and differential impacts on agricultural value chains and the structure of food production, employment, and consumption (Berdegué, Proctor, and Cazzuffi 2014). The large percentage of the population living

7 All three problems constitute the "triple burden of malnutrition" (Pinstrup-Andersen 2011). 
TABLE 6.2 Changing shares of urban population in LAC and other regions

\begin{tabular}{llcccccc}
\hline Regions & Variables & 1960s & 1970s & 1980s & 1990s & 2000s & 2010s \\
\hline $\begin{array}{l}\text { Latin America and } \\
\text { Caribbean (excluding } \\
\text { high income) }\end{array}$ & $\begin{array}{l}\text { Urban population } \\
\text { less than 1 million } \\
\text { (\% of total) }\end{array}$ & 27.4 & 30.7 & 34.8 & 38.8 & 41.3 & 42.9 \\
$\begin{array}{l}\text { Low and middle } \\
\text { income }\end{array}$ & $\begin{array}{l}\text { Urban population } \\
\text { less than 1 million } \\
\text { (\% of total) }\end{array}$ & 15.1 & 16.8 & 19.9 & 22.8 & 25.3 & 28.0 \\
World & $\begin{array}{l}\text { Urban population } \\
\text { less than 1 million } \\
\text { (\% of total) }\end{array}$ & 20.5 & 21.6 & 23.9 & 26.0 & 28.1 & 30.5 \\
$\begin{array}{l}\text { Urban population } \\
\text { (\% of total) }\end{array}$ & 52.0 & 59.6 & 66.5 & 72.2 & 76.4 & 79.0 \\
$\begin{array}{l}\text { Latin America and } \\
\text { Caribbean (excluding } \\
\text { high income) } \\
\text { Low and middle }\end{array}$ & $\begin{array}{l}\text { Urban population } \\
\text { income }\end{array}$ & 25.4 & 28.4 & 33.0 & 37.7 & 42.7 & 47.6 \\
World & $\begin{array}{l}\text { Urban population } \\
\text { (\% of total) }\end{array}$ & 35.2 & 37.6 & 40.9 & 44.5 & 48.7 & 52.9 \\
\hline
\end{tabular}

Source: Data from World Bank (2019).

Note: $L A C=$ Latin America and the Caribbean.

in intermediate and small towns distinguishes LAC from other developing regions, with the exception of developing countries in Eastern Europe and Central Asia (Díaz-Bonilla and Torero 2016). ${ }^{8}$

All those changes present a variety of challenges for agricultural policies in LAC. Therefore, the overall policy framework for agriculture and food production is changing, and the policy objectives related to the sector have also become more complex. With differences depending on the levels of development, the agricultural sector is expected to contribute to the whole economy and society on several fronts. For instance, expanding on PIADAL (2013), it is possible to identify five objectives: (1) growth in agricultural production and productivity as a means to contribute to growth, employment, and economic development in general; (2) reduction of poverty, vulnerability, and food insecurity, considering gender issues; (3) food safety and improvements in nutrition conditions; (4) environmental sustainability and protection of biodiversity; and (5) regional and territorial development, helping to eliminate large income disparities between urban and rural areas.

8 Also, urban centers in LAC are among those most affected by violence and crime, apart from countries at war. In fact, measured by the number of homicides per 100,000 population, the 8 most dangerous cities in the world and 42 of the top 50 are in LAC. See www.worldatlas.com/ articles/most-dangerous-cities-in-the-world.html. 
In consequence, the challenges for policies related to the agriculture sector go beyond what ministries of agriculture can do. The focus has expanded from agricultural development, to broader views of rural and value-chain development, and more recently to food systems, encompassing the previous levels plus retail and consumption aspects (HLPE 2017).

\section{Production and Productivity Growth in Agriculture}

\section{Production}

Table 6.3 shows the growth rates of agricultural production (which is the sum of the two components of the FAOSTAT database labeled "crops" and "livestock") for the three main producing countries, for the LAC region, and for the world, in decades since the 1960s.

LAC's total agricultural production performed better than the world average in all decades. The worst performance for LAC was during the 1980s, the "lost decade" of the debt crisis, when the macro, trade, and sectoral policy reforms that were supposed to help the agriculture sector were in part countered by slow domestic growth and the decline in world prices. In the $2000 \mathrm{~s}$ and 2010s, growth levels returned to those seen in the 1960s and 1970s. This was the result of better performance in South America and particularly Brazil.

In general, crops have been growing faster in more recent decades, pushed mostly by Argentina and Brazil, with the expansion of oilseeds and grains. Livestock grew faster in the 1990s due to Brazil and Mexico, while in Argentina the 2010s were negative for aggregate livestock production, in part because of adverse domestic policies and relative prices that led to the expansion of soybeans to the detriment of pastures (Díaz-Bonilla et al. 2014).

Those differential growth rates changed the structure of agricultural production, as shown in Table 6.4 (divided into the two components of the FAOSTAT database-crops and livestock). The values for agriculture, crops, and livestock are presented for the three main producing countries, for the rest of LAC, for the LAC aggregate, and for the world, in decades since the 1960s. ${ }^{10}$

9 Value of production is measured in constant dollars at purchasing power parity (PPP) values, which FAOSTAT calls "international dollars" (which are different from constant common dollars). This measure avoids fluctuations in the total value of aggregates due to changes in market exchange rates, and it uses a form of adjustment for PPP by which each commodity has a single world price per relevant unit of volume, irrespective of the country where it was produced. This approach facilitates aggregations and comparisons across countries.

10 Data reflect the value of production in constant dollars at PPP values (which are different from constant common dollars). 
TABLE 6.3 Value of agricultural production (average annual growth rates in constant 20042006 PPP dollars)

\begin{tabular}{lcccccc}
\hline Region & $1960 \mathrm{~s}$ & 1970s & 1980s & 1990s & 2000s & 2010s \\
\hline Argentina & 3.0 & 2.2 & -0.4 & 4.1 & 1.4 & 4.8 \\
Brazil & 3.8 & 3.5 & 4.5 & 3.2 & 4.4 & 3.1 \\
Mexico & 4.5 & 3.8 & 1.9 & 3.4 & 1.9 & 2.8 \\
LAC & 3.2 & 3.0 & 2.5 & 3.0 & 3.1 & 3.2 \\
World & 2.8 & 2.4 & 2.2 & 2.1 & 2.4 & 2.3 \\
\hline
\end{tabular}

Source: Authors' calculations based on FAO (2018).

Note: The average for the decades was affected by the strong decline of 2009 and sharp rebound of 2010. LAC = Latin America and the Caribbean; PPP = purchasing power parity.

TABLE 6.4 Share (\%) of value of world agricultural production (in constant 2004-2006 PPP dollars)

\begin{tabular}{llcccccc}
\hline Country or region & Variable & $1960 \mathrm{~s}$ & $1970 \mathrm{~s}$ & $1980 \mathrm{~s}$ & $1990 \mathrm{~s}$ & \multicolumn{1}{c}{$2000 \mathrm{~s}$} & $2010 \mathrm{~s}$ \\
\hline Argentina & Agriculture & 2.0 & 1.8 & 1.7 & 1.7 & 1.8 & 1.8 \\
Brazil & Agriculture & 3.0 & 3.4 & 4.0 & 4.5 & 5.5 & 6.1 \\
Mexico & Agriculture & 1.3 & 1.4 & 1.6 & 1.6 & 1.6 & 1.6 \\
Rest of LAC & Agriculture & 3.2 & 3.3 & 3.2 & 3.2 & 3.3 & 3.2 \\
LAC & Agriculture & 9.5 & 9.9 & 10.5 & 11.0 & 12.2 & 12.7 \\
World & Agriculture & 100 & 100 & 100 & 100 & 100 & 100 \\
Argentina & Crops & 1.3 & 1.4 & 1.4 & 1.5 & 1.8 & 1.8 \\
Brazil & Crops & 3.4 & 3.6 & 4.3 & 4.3 & 5.0 & 5.6 \\
Mexico & Crops & 1.3 & 1.4 & 1.5 & 1.4 & 1.4 & 1.3 \\
Rest of LAC & Crops & 3.4 & 3.4 & 3.2 & 3.2 & 3.1 & 3.1 \\
LAC & Crops & 9.4 & 9.8 & 10.4 & 10.4 & 11.3 & 11.8 \\
World & Crops & 100 & 100 & 100 & 100 & 100 & 100 \\
Argentina & Livestock & 3.0 & 2.6 & 2.2 & 2.0 & 1.8 & 1.7 \\
Brazil & Livestock & 2.5 & 2.9 & 3.7 & 4.8 & 6.4 & 7.0 \\
Mexico & Livestock & 1.2 & 1.5 & 1.8 & 1.8 & 2.0 & 2.0 \\
Rest of LAC & Livestock & 3.0 & 3.0 & 3.0 & 3.4 & 3.7 & 3.8 \\
LAC & Livestock & 9.7 & 10.0 & 10.7 & 12.0 & 13.9 & 14.5 \\
World & Livestock & 100 & 100 & 100 & 100 & 100 & 100 \\
\hline
\end{tabular}

Source: Authors' calculations based on FAO (2018).

Note: $\mathrm{LAC}=$ Latin America and the Caribbean; PPP = purchasing power parity. 
Overall, the relatively stronger growth of LAC's agriculture (Table 6.4) led to the increase in the region's share in world agriculture: it moved from 9.5 percent of world agricultural production in the 1960s (a combination of a share of 9.4 percent in crops and 9.7 percent in livestock) to 12.7 percent in the 2010s (combining 11.8 percent in crops and 14.5 percent in livestock). LAC's increased share of more than 3 percentage points has been due mostly to Brazil's performance, considering that Argentina lost some share, while Mexico did not gain much, and the rest of LAC stayed about the same. In terms of composition of agricultural production, the increase in LAC's share at the world level is related more to the increase of livestock production, as opposed to crops.

A point worth noting is that by the 2010s, LAC's agricultural production (measured in international dollars) had grown somewhat bigger in size than both that of the European Union, on the one hand, and that of the United States and Canada, on the other (both with about 11 percent of global agricultural production each). As a comparison, all Asia represents about 50 percent, and Africa close to 9 percent (Díaz-Bonilla, Saini, Henry, Creamer, and Trigo 2014).

\section{Land, Deforestation, and Greenhouse Gas Emissions}

Agricultural land (including crops and pastures) at the global level increased by about 380 million hectares between the 1960s and the 2010s. ${ }^{11}$ To place LAC in the global context, Table 6.5 shows how much of that change occurred in different producing regions. The LAC region is presented as a whole and also disaggregated into Argentina, Brazil, Mexico, and the rest of LAC. Table 6.5 includes the same calculations as Table 6.3, related to increases in the global share for the value of agricultural production in billions of constant dollars of equivalent purchasing power (or purchasing power parity, $\mathrm{PPP}$ ). ${ }^{12}$

LAC represented 44.1 percent of the world increase in agricultural land during the decades between the 1960s and 2010s, while the share of

11 FAOSTAT uses "agricultural area" as the general category, which has different components such as "arable land," "permanent crops," and "permanent meadows and pastures." In the table we utilize the general category of "agricultural area" because it seems the most comprehensive estimation of land use, and it is particularly relevant for LAC, given the large share of livestock production in the region.

12 Value of production is measured in constant dollars at purchasing power parity (PPP) values, which FAOSTAT calls "international dollars" (which are different from constant common dollars). This measure avoids fluctuations in the total value of aggregates due to changes in market exchange rates, and it uses a form of adjustment for PPP by which each commodity has a single world price per relevant unit of volume, irrespective of the country where it was produced. This approach facilitates aggregations and comparisons across countries. 
TABLE 6.5 Increases in production and area

\begin{tabular}{|c|c|c|c|c|c|c|c|c|}
\hline \multirow[b]{2}{*}{$\begin{array}{l}\text { Country } \\
\text { or region }\end{array}$} & \multicolumn{4}{|c|}{$\begin{array}{c}\text { Net production value } \\
\text { (constant 2004-2006 billion PPP dollars) }\end{array}$} & \multicolumn{4}{|c|}{$\begin{array}{l}\text { Agricultural area } \\
\text { (million hectares) }\end{array}$} \\
\hline & $1960 \mathrm{~s}$ & 2010s & $\begin{array}{l}\text { Percentage } \\
\text { of world } \\
\text { change }\end{array}$ & $\begin{array}{c}\text { Change from } \\
1960 \text { s to } \\
2010 \text { s (\%) }\end{array}$ & $1960 \mathrm{~s}$ & 2010s & $\begin{array}{l}\text { Percentage } \\
\text { of world } \\
\text { change }\end{array}$ & $\begin{array}{c}\text { Change from } \\
1960 \text { s to } \\
2010 \text { s (\%) }\end{array}$ \\
\hline Asia & 248.9 & $1,247.7$ & 62.0 & 401.4 & $1,094.6$ & $1,648.4$ & 145.4 & 50.6 \\
\hline China & 81.1 & 569.4 & 30.3 & 601.8 & 355.1 & 514.6 & 41.9 & 44.9 \\
\hline India & 63.3 & 251.6 & 11.7 & 297.4 & 177.0 & 179.6 & 0.7 & 1.5 \\
\hline LAC & 79.7 & 311.8 & 14.4 & 291.2 & 582.5 & 750.4 & 44.1 & 28.8 \\
\hline Argentina & 16.5 & 43.0 & 1.6 & 160.8 & 132.6 & 148.6 & 4.2 & 12.1 \\
\hline Brazil & 25.7 & 148.6 & 7.6 & 478.8 & 170.9 & 277.2 & 27.9 & 62.2 \\
\hline Mexico & 10.8 & 38.1 & 1.7 & 253.9 & 98.0 & 106.7 & 2.3 & 8.9 \\
\hline $\begin{array}{l}\text { Rest of } \\
\text { LAC }\end{array}$ & 26.8 & 82.1 & 3.4 & 206.6 & 181.1 & 217.9 & 9.7 & 20.3 \\
\hline Africa & 58.0 & 210.5 & 9.5 & 262.9 & $1,048.1$ & $1,130.2$ & 21.6 & 7.8 \\
\hline $\begin{array}{l}\text { European } \\
\text { Union }\end{array}$ & 188.4 & 269.4 & 5.0 & 43.0 & 209.9 & 186.6 & -6.1 & -11.1 \\
\hline $\begin{array}{l}\text { USA and } \\
\text { Canada }\end{array}$ & 131.9 & 268.9 & 8.5 & 103.9 & 508.9 & 471.6 & -9.8 & -7.3 \\
\hline $\begin{array}{l}\text { Australia } \\
\text { and New } \\
\text { Zealand }\end{array}$ & 16.9 & 37.7 & 1.3 & 123.7 & 486.8 & 414.6 & -19.0 & -14.8 \\
\hline World & 841.3 & $2,452.5$ & 100 & 191.5 & $4,504.3$ & $4,885.1$ & 100 & 8.5 \\
\hline
\end{tabular}

Source: Authors' calculations based on FAO (2018).

Note: $\mathrm{LAC}=$ Latin America and the Caribbean; PPP = purchasing power parity.

the increase in world agricultural production during that same period was 14.4 percent. Therefore, LAC's increase in agricultural and food production and exports (see below), although benefiting from improvements in productivity, was also associated with an important expansion of agricultural area based on land-use changes that will be difficult to repeat in the future without compromising sustainability.

The increase in agricultural land happened mostly in Brazil and, to a smaller degree, in the rest of LAC, while Mexico and Argentina experienced relatively minor expansions.

The expansion in agricultural land has been closely linked to deforestation (Table 6.6). LAC lost about 10 percent of its forest between 1990 and 2015, while the world lost about 3 percent. Overall, the region represented more than 80 percent of all the forest lost at the world level during that period. 
TABLE 6.6 Forest area (million hectares)

\begin{tabular}{lrrrc}
\hline Region & \multicolumn{1}{c}{ Lost } & $\begin{array}{c}\text { Lost forest as } \\
\text { percentage of total } \\
\text { forest in 1990 }\end{array}$ \\
\hline World & $4,128.3$ & $4,007.4$ & -120.9 & -2.9 \\
LAC & $1,007.0$ & 906.3 & -100.7 & -10.0 \\
\hline LAC as percentage of world & 24.4 & 22.6 & 83.3 & \\
\hline
\end{tabular}

Source: Authors' calculations based on FAO (2018).

Note: $L A C=$ Latin America and the Caribbean.

Therefore, even though LAC represents only 10 percent of all greenhouse gas (GHG) emissions at the world level, the region has comparatively higher levels of GHG emissions related to agriculture and land-use change and forestry (LUCF). According to the database of emissions from FAOSTAT, in the decade of the 2010s LAC represented about 22 percent of all world emissions, combining agriculture and LUCF emissions, with Brazil accounting for some 44 percent of LAC's total for that aggregate.

Therefore, the loss of forest cover should be monitored to ensure long-term sustainability (as is done with the satellite data collected by Terra-I, a project of CIAT) ${ }^{13}$ Rapid land-use change is putting pressure on LAC's role as a major provider of global environmental public goods, including biodiversity, oxygen, and carbon sinks.

\section{Labor}

Table 6.7 shows that the region has far smaller shares of employment in agriculture than both developing countries and the world, but with great variations: along with Brazil and Mexico, which are the largest countries in the region, two other countries are included, as representatives of lower (Venezuela) and higher (Haiti) levels of agricultural employment in the region. ${ }^{14}$

The fact that LAC has expanded the land area utilized but reduced employment in agriculture is reflected in the differential productivity levels for land and labor, as discussed below.

13 See www.terra-i.org/terra-i.html for information about Terra-I.

14 Some small island countries in the Caribbean show lower levels than Venezuela. Data for Argentina is not included because of the limited coverage of household surveys. 
TABLE 6.7 Employment in agriculture (\% of total employment)

\begin{tabular}{lccc}
\hline Countries and regions & 1990s & 2000s & 2010s \\
\hline LAC & 22.1 & 19.0 & 14.9 \\
Brazil & 21.2 & 19.2 & 11.6 \\
Mexico & 23.4 & 15.5 & 13.5 \\
Venezuela & 12.0 & 9.8 & 7.5 \\
Haiti & 50.6 & 50.4 & 50.0 \\
Low and middle income & 50.3 & 44.8 & 36.0 \\
World & 41.7 & 37.3 & 30.2 \\
\hline
\end{tabular}

Source: Data from World Bank (2019).

Note: $L A C=$ Latin America and the Caribbean.

\section{Productivity}

The worldwide efficiency in land and labor use increased on average between 1961 and 2010 (Pardey 2012). In particular, LAC increased output per worker by about 270 percent during that period, and output per hectare some 205 percent (measured in 2004-2006 international dollars). But there are clear differences between regions and countries: Latin America shows less labor and land productivity than in all developed regions (except for Australia and New Zealand, which have less land productivity than LAC) while being above the world average and that of all developing regions (except Eastern Europe) in labor productivity, but only exceeding Africa south of the Sahara and countries of the former Soviet Union when considering land productivity (Pardey 2012; see also Chapter 1).

Figures 6.2, 6.3, and 6.4, following Hayami and Ruttan (1985), present several indicators of partial productivity. ${ }^{15}$ The indicators are presented for the region only, comparing the averages for three decades-1960s, 1990s, and 2010s - and separating Argentina, Brazil, Mexico, and the rest of LAC (which is the simple average of the remaining countries in the database) ${ }^{16}$

Argentina, due to its large land area (Figure 6.3), has the lowest ratio of product per unit of land (Figure 6.2), but a low labor-land ratio (the inverse

15 Data come from the IFPRI (2019) database maintained by Alejandro Nin-Pratt, which also uses data from the USDA Economic Research Service Agricultural Productivity project and FAOSTAT (see also Fuglie 2012 and 2015). Figures 6.2-6.4 follow Hayami and Ruttan (1985; see also Kawagoe, Otsuka, and Hayami 1986). The variables are defined in the figure notes. The data is presented in normal units (not logarithms) to facilitate interpretation.

16 Those countries are Bolivia, Chile, Colombia, Costa Rica, Dominican Republic, Ecuador, El Salvador, Guatemala, Guyana, Haiti, Honduras, Jamaica, Nicaragua, Panama, Paraguay, Peru, Suriname, Trinidad and Tobago, Uruguay, and Venezuela. 
FIGURE 6.2 Product per unit of land (Q/A) and product per unit of labor (Q/L)

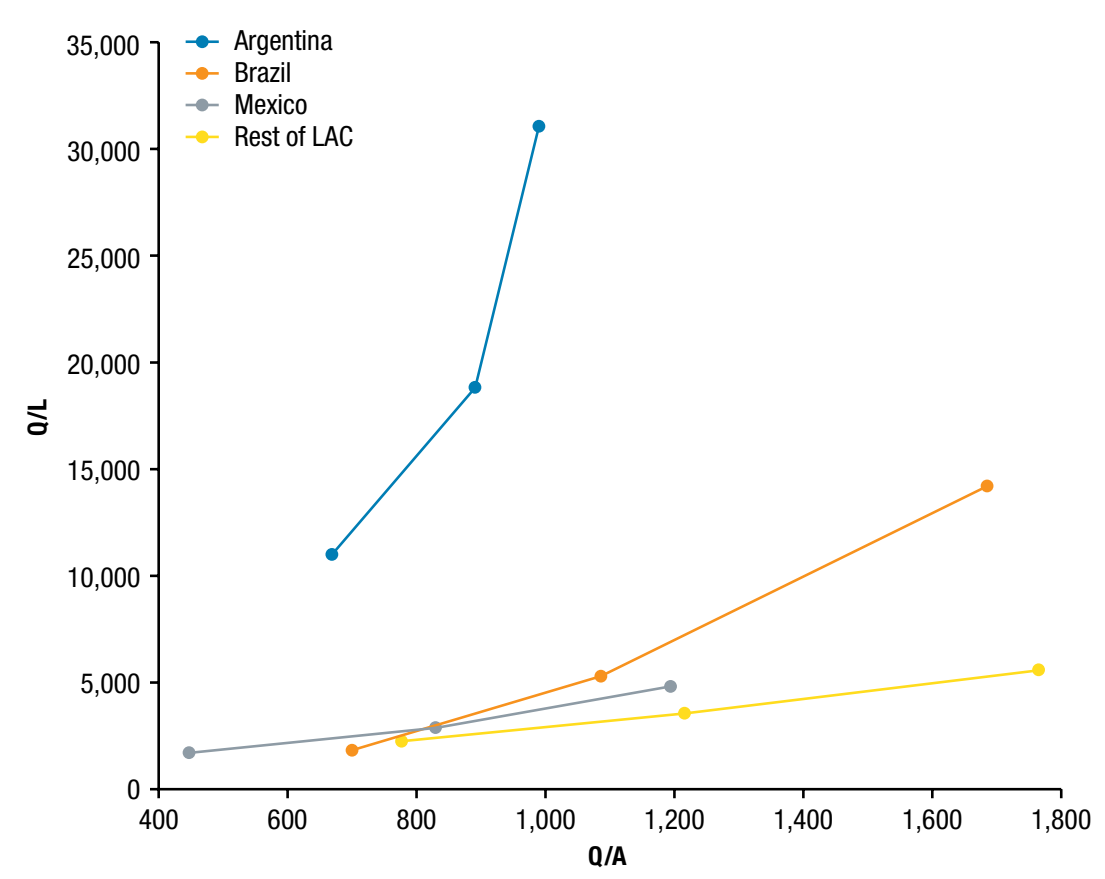

Source: Authors' calculations using IFPRI (2019).

Note: $A$ = land (total agricultural land in hectares of "rainfed cropland equivalents"); $L$ = labor (persons economically active in agriculture); $Q$ = output (FAO gross agricultural output, measured in international 2005 dollars); LAC = Latin America and the Caribbean.

of the indicator in Figure 6.3) combined with larger mechanization ratios (Figure 6.3) and natural fertility leads to the largest ratio of product per unit of labor (Figure 6.2), even with low levels of use of fertilizers (Figure 6.4). Mexico, far more constrained in land per worker (Figure 6.3) while still having an important agricultural population with lower levels of capital use (Figure 6.3) and fertilizer application (Figure 6.4), shows the lowest ratios of product per land and labor. Brazil and the rest of LAC are in between those two countries in terms of partial productivity of land (Figure 6.2), but Brazil is clearly above the rest of LAC in the ratio of product per unit of labor (Figure 6.2), resulting from larger indices of capital per unit labor (Figure 6.3) and fertilizer use (Figure 6.4). Also noticeable in Brazil is the strong growth of the level of production per unit of labor (almost 680 percent since the 1960s), supported by large increases in land and capital per unit of labor (Figure 6.3) 


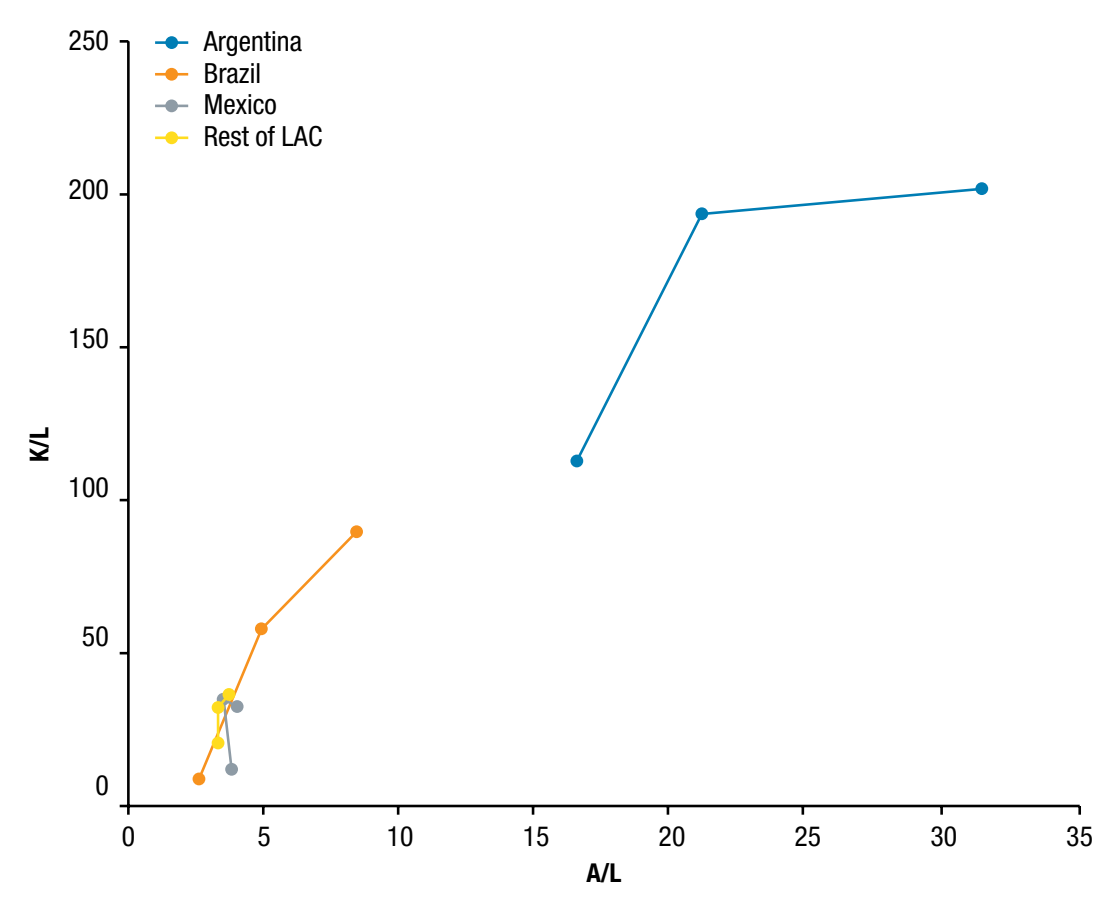

Source: Authors' calculations using IFPRI (2019).

Note: $\mathrm{A}=$ land (total agricultural land in hectares of "rainfed cropland equivalents"); $\mathrm{K}=$ capital (total stock of farm machinery in "40-CV tractor equivalents" (CV is a measure of horsepower). LAC = Latin America and Caribbean.

and in the use of fertilizers (Figure 6.4). ${ }^{17}$ To sum up, the observation that high (or low) land-labor ratio is associated with high (or low) capital-labor ratio and high (or low) labor productivity is consistent with the HayamiRuttan (1985) induced innovation hypothesis.

A more comprehensive approach to the evolution of productivity in LAC is to analyze the growth rate of total factor productivity (TFP).$^{18}$ Nin-Pratt et al. (2015), looking at TFP growth in LAC agriculture between 1980 and 2012, show that regional agricultural output per worker and TFP increased 82 and

17 For instance, Bustos, Caprettini, and Ponticelli (2016) show significant technical change in soybean production in Brazil that has been strongly laborsaving and led to structural transformation.

18 It should be noted that the calculation of total agricultural production is a composite of products measured in constant prices of a certain base year. Therefore, that "quantity" can increase also because of composition effects (for example, if a country reduces the share of lower-price products and increases the share of higher-value ones). 


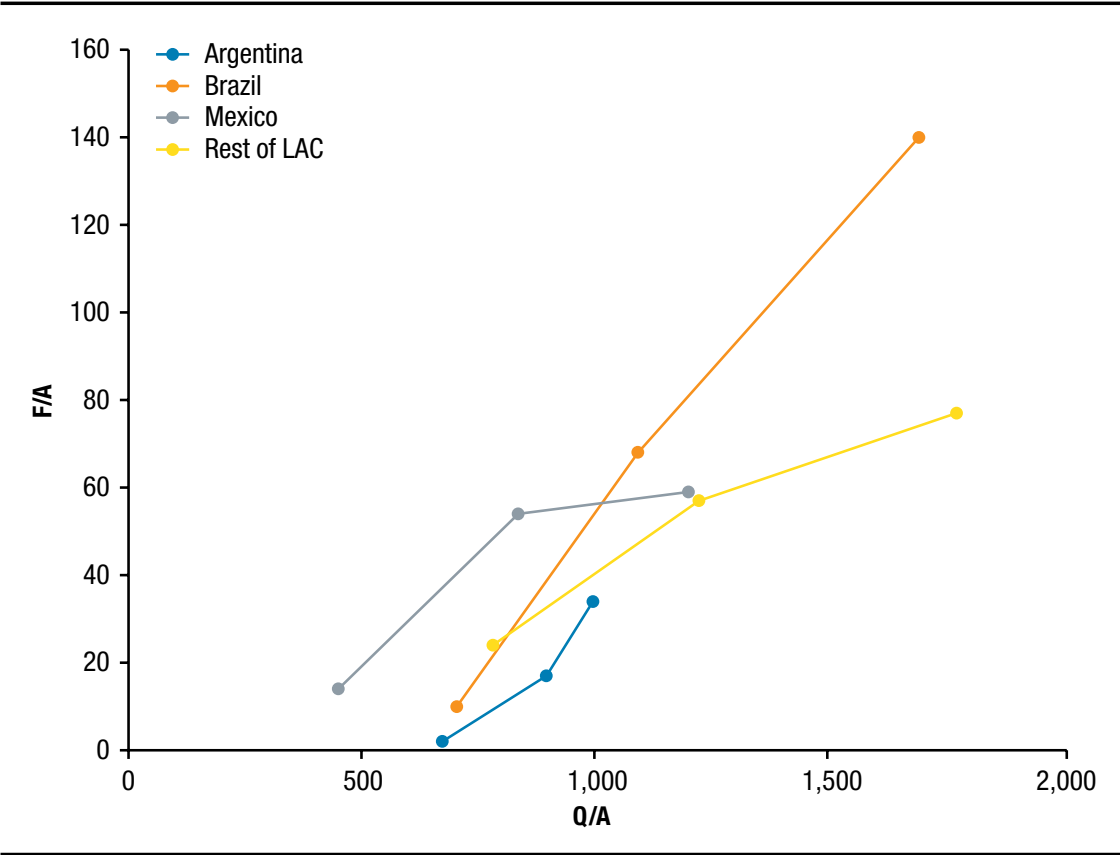

Source: Authors' calculations using IFPRI (2019).

Note: $\mathrm{A}=$ land (total agricultural land in hectares of "rainfed cropland equivalents"); $\mathrm{F}=$ fertilizer (metric tons of $\mathrm{N}-\mathrm{P}_{2} \mathrm{O}_{5}-\mathrm{K}_{2} \mathrm{O}$ fertilizer consumption measured in "N-fertilizer equivalents"); $\mathrm{LAC}=$ Latin America and the Caribbean; $\mathrm{Q}=$ output (FAO gross agricultural output, measured in international 2005 dollars).

45 percent, respectively. The authors attribute the improved performance to the use of fertilizer, increases in land productivity, and growth in the use of capital that expanded cultivated area per worker, as well as to higher productivity of the animal stock.

Table 6.8 shows the latest estimates from IFPRI (2019) for LAC compared with other regions and differentiating Argentina, Brazil, Mexico, and the rest of LAC. ${ }^{19}$

LAC was behind all developing regions in TFP growth except the Middle East and North Africa during 1991-2000 (affected by Argentina’s low growth) but outperformed all regions during the next two periods shown in Table 6.8. Brazil and Mexico maintained a reasonably strong TFP growth during the years considered.

19 The countries are the same as for Figures 6.2 to 6.4, except Venezuela. 
TABLE 6.8 Growth of TFP (\% annual)

\begin{tabular}{lccc}
\hline Region/country & $\mathbf{1 9 9 1 - 2 0 0 0}$ & $\mathbf{2 0 0 1 - 2 0 1 0}$ & $\mathbf{2 0 1 1 - 2 0 1 5}$ \\
\hline Africa south of the Sahara & 1.5 & 1.0 & 0.4 \\
Asia & 1.7 & 1.7 & 1.5 \\
Middle East and North Africa & 1.3 & 1.5 & 1.2 \\
Latin America and Caribbean & 1.3 & 2.3 & 1.9 \\
Argentina & 0.2 & 0.9 & 3.4 \\
Brazil & 1.6 & 3.3 & 1.6 \\
Mexico & 2.2 & 2.0 & 2.2 \\
Rest of LAC (average) & 0.8 & 1.7 & 1.9 \\
\hline
\end{tabular}

Source: IFPRI (2019).

Note: $L A C=$ Latin America and the Caribbean; TFP = total factor productivity.

The positive trends in LAC's partial and total factor productivity in the recent past took place within a relatively favorable global macroeconomic environment and higher commodity prices. Sustaining future agricultural productivity trends in the region under conditions that will likely be less favorable will require important investments in agricultural research (Pardey and Beintema 2001; Fan 2008).

\section{Food Security and Nutritional Transition}

\section{Food Availability}

Food availability per capita has increased between the 1960s and the current decade in LAC and worldwide (Table 6.9). While in the 1960s the average number of daily calories per capita was between somewhat more than 2,100 and 2,300 depending on the subregions of LAC, the averages for the decade of the 2010s were between about 2,700 and more than 3,000 calories per day per person. Daily proteins per capita increased from 51-64 grams (1960s) to about 67-85 (2010s), while fats moved from 47-52 grams per capita (1960s) to 70-100 (2010s). Mexico and Central America, and South America (the largest LAC subregions considered in the data) have maintained absolute values of food availability above world averages; the Caribbean region, where Haiti has a large influence in the aggregates due to its large population, is below the world average, but availability per capita has still grown about 27 percent in calories, 31 percent in proteins, and almost 50 percent in fats. 
TABLE 6.9 Food availability

\begin{tabular}{|c|c|c|c|c|}
\hline Regions & Variable & 1960s & 2010s & Change (\%) \\
\hline Caribbean & $\begin{array}{l}\text { Fat supply quantity (grams/ } \\
\text { capita/day) }\end{array}$ & 47.0 & 70.4 & 49.6 \\
\hline $\begin{array}{l}\text { Mexico and Central } \\
\text { America }\end{array}$ & $\begin{array}{l}\text { Fat supply quantity (grams/ } \\
\text { capita/day) }\end{array}$ & 48.9 & 85.0 & 73.7 \\
\hline South America & $\begin{array}{l}\text { Fat supply quantity (grams/ } \\
\text { capita/day) }\end{array}$ & 52.2 & 99.6 & 90.7 \\
\hline World & $\begin{array}{l}\text { Fat supply quantity (grams/ } \\
\text { capita/day) }\end{array}$ & 50.9 & 82.4 & 62.0 \\
\hline Caribbean & Food supply (kcal/capita/day) & $2,127.6$ & $2,699.0$ & 26.9 \\
\hline $\begin{array}{l}\text { Mexico and Central } \\
\text { America }\end{array}$ & Food supply (kcal/capita/day) & $2,271.6$ & $2,920.0$ & 28.5 \\
\hline South America & Food supply (kcal/capita/day) & $2,393.8$ & $3,014.0$ & 25.9 \\
\hline World & Food supply (kcal/capita/day) & $2,291.6$ & $2,869.3$ & 25.2 \\
\hline Caribbean & $\begin{array}{l}\text { Protein supply quantity (grams/ } \\
\text { capita/day) }\end{array}$ & 50.9 & 66.6 & 30.9 \\
\hline $\begin{array}{l}\text { Mexico and Central } \\
\text { America }\end{array}$ & $\begin{array}{l}\text { Protein supply quantity (grams/ } \\
\text { capita/day) }\end{array}$ & 61.1 & 81.7 & 33.6 \\
\hline South America & $\begin{array}{l}\text { Protein supply quantity (grams/ } \\
\text { capita/day) }\end{array}$ & 64.0 & 85.2 & 33.2 \\
\hline World & $\begin{array}{l}\text { Protein supply quantity (grams/ } \\
\text { capita/day) }\end{array}$ & 63.2 & 80.6 & 27.5 \\
\hline
\end{tabular}

Source: Authors' calculations based on FAO (2018).

\section{Income Growth, Poverty, and Inequality}

During recent decades LAC countries also showed other important socioeconomic changes. Since the 1960 s, gross domestic product (GDP) per capita (in constant $\$ 2010$ dollars) increased by 130 percent to almost $\$ 9,500$ dollars per capita (average of the 2010s), clearly above the less than $\$ 4,200$ dollars for all developing countries, but still far below the more than $\$ 41,000$ dollars per capita of developed countries (World Bank 2018).

That growth of income was accompanied by the traditional process of structural transformation in which agriculture declines as percentage of total value-added: though the sector had represented about 14.6 percent of total GDP for LAC during the 1960s, it declined to 5.5 percent by the 2010s. There is still an important variation across countries in LAC, with Haiti, Paraguay, Nicaragua, Belize, Honduras, Bolivia, El Salvador, Guatemala, and Suriname showing percentages of agricultural GDP above 10 percent of total GDP, while in Chile, Mexico, and Trinidad and Tobago those shares are 
below 5 percent. Rural population was also falling, moving from 48 percent of total population in the 1960 s to 21 percent in the 2010 s.

The percentage of population suffering from poverty declined from almost 17 percent on average in the 1980s to 5.8 percent for the 2010s (using a poverty line of US $\$ 1.9$ per day in PPP terms), levels that are less than half the average for developing countries (Table 6.10).

In fact, the region has achieved the Millennium Development Goal (MDG) to cut the incidence of poverty by half by $2015 .^{20}$

Another point to be noted is that in LAC, poverty has become mostly urban since the 1990s, when the number of urban poor started to exceed the rural poor; early in the 2010s about two-thirds of the poor lived in urban areas. Still, the incidence of poverty is higher in rural areas. Also, the incidence of poverty is higher among the indigenous population and among households that depend on agricultural income or on government transfers (CEPAL, FAO, and IICA 2012).

With regard to food security, LAC also shows better indicators than other developing regions (von Grebmer et al. 2016). The region has achieved as well two other 2015 MDGs, by cutting in half the percentage of both underweight children under five years of age and undernourishment in the total population. Latin America (without the Caribbean) has also reached the goal set by the 1996 World Food Summit of cutting the total number of undernourished people in half (Díaz-Bonilla and Torero 2016).

However, while the region shows significant improvements as a whole, food security conditions are still worrisome in some countries, such as Haiti, Honduras, and Guatemala, and in disadvantaged regions in bigger countries.

Several factors appear to have supported the achievement in poverty reduction and food security, including the relatively strong performance of the agriculture sector in recent decades (as discussed above), the decline in poverty resulting from economic growth, and the expansion of safety nets based on cash transfers for the poor and vulnerable, since the second half of the 1990s. Compared with other regions, LAC shows the highest coverage by social safety nets of the poorest 20 percent of the population: in LAC more than 50 percent of the population in that quintile are covered, while in Eastern Europe and Central Asia and East Asia and the Pacific less than 50 percent are covered, and in Africa, South Asia, and the Middle East and Northern Africa less than 30 percent are covered (World Bank 2014; DíazBonilla and Torero 2016). Other factors that have arguably contributed to the

20 With a poverty line of US $\$ 1.25$ (PPP measured in 2005 prices). 
TABLE 6.10 Poverty indicators (poverty head count ratio, \% of population)

\begin{tabular}{llcc}
\hline Regions & $\begin{array}{l}\text { Poverty line } \\
\text { (in 2011 PPP) }\end{array}$ & 1980s & 2010s \\
\hline Latin America and Caribbean & At \$1.90/day & 16.6 & 5.8 \\
Low and middle income & At \$1.90/day & 47.1 & 15.4 \\
World & At \$1.90/day & 38.5 & 13.0 \\
Latin America and Caribbean & At \$3.10/day & 30.8 & 12.5 \\
Low and middle income & At \$3.10/day & 67.6 & 35.8 \\
World & At \$3.10/day & - & - \\
\hline
\end{tabular}

Source: Data from World Bank (2019).

Note: $-=$ not available; PPP $=$ purchasing power parity.

region's achievements include advances in the education and status of women; improvements in water, sanitation, and health infrastructure; and the spread of democracy in the region since the 1980s and 1990s (Díaz-Bonilla and Torero 2016).

At the same time, it should be noted that for all its advances in income and declines in poverty and food insecurity, LAC remains the most unequal region in the world (an average Gini of about 0.51 for the countries with data in the World Bank database), closely followed by Africa south of the Sahara (Gini of 0.47).

\section{Nutritional Transition}

Helped by improvements in income, food security, and health care, the average inhabitant of LAC countries reached about 76 years of life expectancy at birth in the latest year with data in the World Development Indicators (World Bank 2018) (adding 20 years since 1960), compared with 71 years of life expectancy for developing countries as a whole, but some 81 years for developed countries.

However, the decline in poverty and food insecurity in the region has been accompanied by problems of overweight and obesity, part of the triple burden of malnutrition mentioned above (Pinstrup-Andersen 2011). Table 6.11 shows that LAC suffers from a high incidence of overweight and obesity compared with the world average.

Popkin and Reardon (2018) have clearly shown that the region faces a major diet-related health challenge with great economic and social costs. The significant increase-among all ages_of overweight and obese levels can be explained by a shift toward consumption of less-healthful low-nutrient-density foods and sugary beverages as well as changes in away-from-home eating and 
TABLE 6.11 Overweight and obesity, 2016 (\%)

\begin{tabular}{lccccc}
\hline & \multicolumn{2}{c}{ Average in LAC } & & \multicolumn{2}{c}{ Average in world } \\
\cline { 2 - 3 } \cline { 5 - 6 } Gender and age & Overweight & Obese & & Overweight & Obese \\
\hline Adolescents, male & 30.0 & 10.4 & & 17.5 & 5.6 \\
Adolescents, female & 31.2 & 13.5 & & 19.2 & 7.8 \\
Adults, male & 58.5 & 20.2 & & 24.8 & 11.6 \\
Adults, female & 60.1 & 28.0 & & 28.4 & 15.7 \\
\hline
\end{tabular}

Source: Authors' calculations from Development Initiatives (2018).

Note: $L A C=$ Latin America and the Caribbean.

snacking. As a result, governments in the region have started to adopt stricter labeling regulations (such as in Chile, Peru, and Ecuador) and to impose taxes on unhealthy food (Mexico). Moreover, deficiencies in critical nutrients, such as iron and vitamin A, also constitute a problem (see the 2018 Global Nutrition Report by Development Initiatives).

\section{Innovations and Agricultural Transformation}

Global and regional agrifood systems are undergoing remarkable changes, while facing a series of major challenges, including sustainable intensification, contribution to global and regional food security, adaptation to and mitigation of climate change, territorial development and the role of "family agriculture," and many more. Facing such challenges requires new approaches and innovative institutional arrangements as well as strengthened agrifood research and innovation.

\section{Investments in Research and Development}

In 2011, only 5 percent of total global investments in public and private research and development $(\mathrm{R} \& \mathrm{D})$ were directed to food and agriculture (Pardey 2012). That small percentage represented US\$69.3 billion (in 2009 purchasing-power-adjusted currency) with a decreasing trend (for a total of 55 percent) in high-income countries and significant growth (representing 43 percent) in middle-income countries, compared with 1980.

Stads et al. (2016) show that agricultural R\&D spending in LAC (excluding the private for-profit sector), after following a period of volatility and declines until the early 2000s, recovered after 2004. By 2013, the region spent US\$5.1 billion on agricultural R\&D (2011 PPP prices), representing a 75 percent increase over levels recorded in the early 1980s; total researcher 
FIGURE 6.5 Long-term trends in agricultural researchers and research spending in LAC, 1981-2013

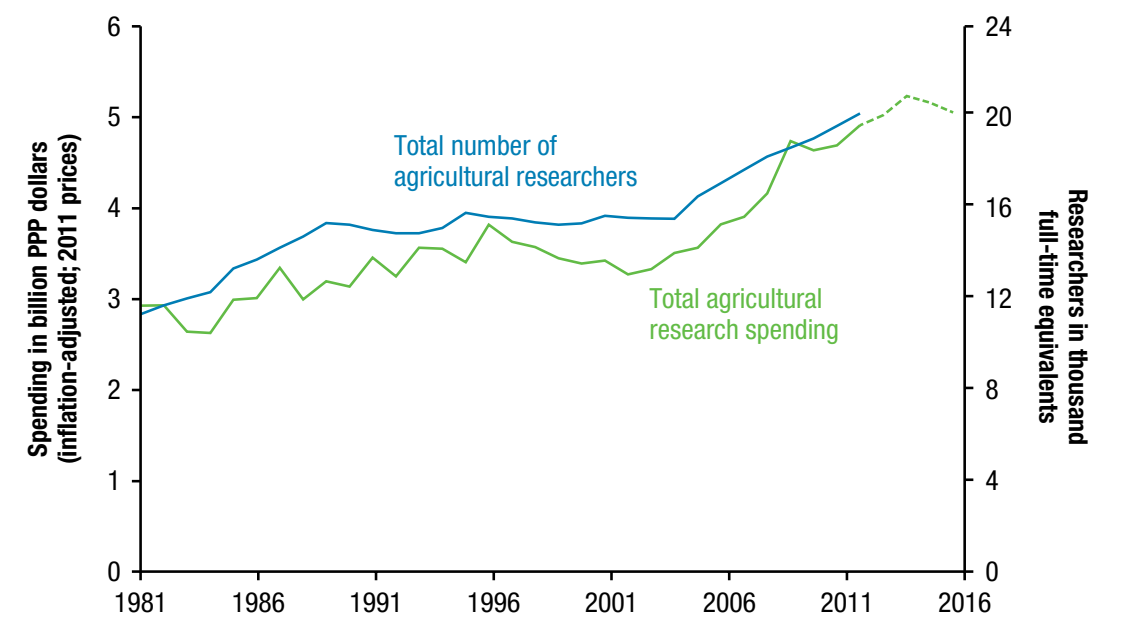

Source: Underlying datasets from Beintema, Nin-Pratt, and Stads (2020).

Note: $L A C=$ Latin America and the Caribbean. The 2013-2016 spending trend is an estimate using various secondary data sources. PPP = purchasing power parity.

numbers (measured in full-time equivalents) also recovered after a period of stagnation during 1990-2004: in 2013, there were about 20,600 agricultural researchers (in full-time equivalents, FTEs), about double the number in the early 1980s. Figure 6.5 shows the evolution of expenditures and researchers in agricultural R\&D.

These trends have been driven mostly by Brazil ( 53 percent of the total in LAC), and to a smaller degree by Argentina (13.5 percent) and Mexico (14 percent), which together represented about 80 percent of LAC's spending and some 75 percent of agricultural researchers (Stads et al. 2016). The Agricultural Science and Technology Indicators (ASTI) database, on which Stads et al. (2016) is also based, shows that by 2013, LAC expenditures in agricultural R\&D represented almost 26 percent of the total by developing countries. As a comparison, in the same year China represented 48.2 percent and India 16.5 percent. Stads et al. (2016) summarize the source of LAC agricultural research funding and its use in $2012 / 2013$. Three features portray important challenges for the future of the region: governments are still the main source of funding for agricultural research; most of that funding is being spent to cover researchers' salaries; and most researchers did not hold a $\mathrm{PhD}$ in the mid-2010s. Approximately 55 percent of agricultural researchers in 
2012/2013 were public-sector employees; universities accounted for 40 percent and nonprofit agencies for 5 percent. ${ }^{21}$

Another useful indicator is the intensity ratio of $R \& D$ (that is, expenditures in $\mathrm{R} \& \mathrm{D}$ over the value of agricultural production). ${ }^{22}$ Calculations by Pardey (2012) show that the research intensity in LAC for the public sector marginally improved in the 1990s and mid-2000s, from 0.8 percent to somewhat more than 1 percent, but that is far less than in high-income countries, particularly if public and private expenditures are considered together. The level of patenting and publications in LAC is also lower than that of developed countries and even some developing countries, such as China (Pardey 2012). On the other hand, LAC shows better ratios of R\&D intensity than the average for developing countries (Pardey 2012). In that regard, Latin America has been an institutional laboratory on funding mechanisms for agricultural research (Echeverría, Trigo, and Byerlee 1996). Some research agencies conduct research on a contract basis for the private sector and through the commercial sale of improved seed. In addition, several countries have established levies on the value of agricultural production. ${ }^{23}$

However, estimates of the intensity ratio (Table 6.12) show an important dispersion in the region (it is the average of the decade of the 2010s). Also, those intensity ratios, even in the countries with the highest value, do not reach 2 percent of agricultural GDP, while in developed countries they usually go above $4-5$ percent.

Furthermore, a significant number of countries are below the 1.0 percent intensity (the minimum recommended by the UN). This remains a big challenge for these countries where government support for agricultural $R \& D$ is too low to sustain viable agricultural research programs capable of addressing current and future priorities. Traditionally, such a research capacity gap has been to a certain extent filled by multicountry initiatives such as subregional cooperative research programs (generically referred to in Spanish as PROCIs, for programas cooperativos de investigación) complementing weak national

21 It is worth noting that universities have gained prominence in agricultural research, especially in Argentina, Bolivia, Costa Rica, Paraguay, and Uruguay. Producer organizations in Colombia and Honduras explain 40 percent of the total number of researchers.

22 Like any indicator, the intensity of $R \& D$ has its problems of interpretation, starting with the fact that it may increase not because $R \& D$ has gone up, but because agricultural GDP has gone down (Beintema et al. 2012).

23 For example, the Colombian coffee, sugarcane, and oil palm producer organizations fund most of their research using a levy on production. Uruguay's National Agricultural Research Institute (INIA) is partly funded by a commodity tax on the total value of the sale of the country's agricultural commodities, and the government matches the funds generated by the tax. 
TABLE 6.12 Investments in public research and development as percentage of agricultural gross domestic product (average 2010s)

\begin{tabular}{lcllll}
\hline \multicolumn{2}{c}{$1 \%$ or more } & \multicolumn{2}{c}{$0.5 \%-0.9 \%$} & \multicolumn{2}{c}{ Less than $0.5 \%$} \\
\hline Brazil & 1.9 & Bolivia & 0.9 & Nicaragua & 0.4 \\
Chile & 1.7 & Jamaica & 0.9 & Peru & 0.4 \\
Uruguay & 1.4 & Panama & 0.8 & Dominican Republic & 0.3 \\
Argentina & 1.2 & Belize & 0.7 & Paraguay & 0.3 \\
Mexico & 1.1 & Colombia & 0.7 & Venezuela & 0.3 \\
Costa Rica & 1.0 & & & Ecuador & 0.2 \\
& & & & Honduras & 0.2 \\
& & & & Guatemala & 0.1 \\
\hline
\end{tabular}

All countries in ASTI database

\begin{tabular}{llll}
\hline Average & 0.9 & Median & 0.5 \\
\hline
\end{tabular}

Source: ASTI (2017).

capacities, as well as regional and subregional funding mechanisms (for example, FONTAGRO).

It should be noted that the region is an important user of biotechnology products. Globally, it has been estimated that 26 countries planted almost 190 million hectares in 2017 (ISAAA 2017). After the United States (75 million hectares, 40 percent of the world total), the next two countries were Brazil (50.2 million hectares, 26 percent of the world total) and Argentina (23.6 million hectares, 12 percent). In total, there are 10 countries in LAC with more than 79 million hectares planted with biotech products (ISAAA 2017). ${ }^{24}$

\section{Technological and Institutional Innovations}

The institutional structure and policies for funding and executing public agricultural research have undergone important changes in Latin America and the Caribbean since the early 1960s, when national agricultural research institutes (NARIs) were conceived and when international centers based in the region were set up. ${ }^{25}$ In addition, the region has been prolific in the

24 In addition to Brazil and Argentina, in 2017 the next countries in order of importance were Paraguay (3 million hectares); Bolivia (1.3 million hectares); Uruguay (1.1 million hectares); Mexico and Colombia with about 0.1 million hectares each; and Honduras, Chile, and Costa Rica, with less than 0.1 million hectares each.

25 Also, starting earlier than other developing regions, LAC has hosted since the 1960s three of the international centers of the CGIAR system: the International Center for Tropical Agriculture 
establishment of various regional and subregional cooperative research mechanisms to execute and also to fund research.

As already pointed out, in the 1980s and 1990s macroeconomic crises led to important changes in agricultural policies in the LAC region, with the dismantling of many agricultural public institutions. Some NARIs started to focus more on small farmers and poverty issues, as part of a broader strategy for rural development.

The regional institutional framework for the development and diffusion of agricultural technology also expanded over time to include other regional institutions. ${ }^{26}$ There was also increased participation of multinational companies, producer associations, universities, and civil society (Byerlee and Echeverría 2002).

As the agrifood systems modernized, they exerted new demands on all these traditional research structures.

The relatively recently substantial transformation of global food systems has several key implications for agricultural research strategies of international and national research systems, particularly in LAC countries well connected to international markets (Reardon et al. 2019). A key requirement is to consider the whole food system and its transformation in order to adopt strategies and designs of innovations in technologies and products related to overall food systems transformations. For instance, emerging requirements in terms of product types, quality and safety attributes, shelf life, cost, consistency, and seasonality should influence research priorities. Farmers themselves are far more involved in markets and commercialization than just a few decades ago, having significantly intensified and diversified farming; therefore, public research strategies need to keep up with that change. In addition, and because innovations are part of a supply chain, it is important to understand the strategies and needs of private-sector actors other than farmers, who are essential in the entire food system. Hence, public research organizations face a growing demand to transform themselves to the new food systems' realities, considering the presence of more actors, which requires new forms of collaboration (Byerlee and Echeverría 2002).

All these changes in the context where agricultural research takes place, new demands on food systems as well as new global challenges such as climate

(CIAT), the International Maize and Wheat Improvement Center (CIMMYT), and the International Potato Center (CIP).

26 Cooperation programs, such as the PROCISUR, PROCIANDINO, PROCITROPICOS, SICTA, PROMECAFE, PROCICARIBE, and PROCINORTE; FORAGRO; regional centers such CATIE and CARDI; and FONTAGRO (Regional Fund for Agricultural Technology). 
change, and new funding opportunities and alternative providers of research solutions imply that, among other challenges, the public research community needs to take into consideration the importance of policy contexts as well as research on the off-farm components of the food system. Reardon et al. (2018) suggest that "research on and productivity of processing, packaging, logistics, and commerce technologies have equal weight in the performance of the food system relative to the farm sector, and investment in research and development value chains for these technologies and value chains for the inputs to these segments need a much higher profile in the context of the transformed food system where post farm segments occupy $40-70 \%$ of value added." In addition, returns to investments at the farm level are very well linked to related innovations in the whole supply chain, from inputs to marketing of final products.

Other challenges include the convergence of life sciences (including those related to agriculture) with physics, chemistry, computer sciences, mathematics, and engineering, leading to the emergence of new interdisciplinary research areas (Committee on a New Biology for the 21st Century 2009; MIT 2011). This challenges NARIs' institutional structures, organized into separate compartments of traditional disciplines related to agricultural R\&D. Not only does such convergence require collaboration between disciplines, but more fundamentally, it calls for true disciplinary integration as well as new forms of funding (Committee on a New Biology for the 21st Century 2009; MIT 2011).

Further, there is the multiplicity of demands now placed on agriculture, in addition to increasing supply and alleviating poverty, which include health and nutrition, equity and gender integration, environmental sustainability, and a broader view of the bioeconomy. The implication of these multiple demands is that agricultural R\&D needs to go beyond an exclusive focus on primary production to include the forward and backward linkages of the value chain, considering the views of a variety of social actors. All of this requires moving from more limited $\mathrm{R} \& \mathrm{D}$ strategies to a broader innovation approach and implies new organizational approaches, particularly to coordinate across multiple actors and networks, and, also, innovative funding arrangements (Trigo 2012).

\section{Irrigation}

Irrigation is another important source of productivity. Table 6.13 shows the area equipped for irrigation in LAC compared with the world. Although the irrigated area in LAC has increased more than the world average since the 
TABLE 6.13 Irrigation

\begin{tabular}{|c|c|c|c|c|}
\hline \multirow{2}{*}{$\begin{array}{l}\text { Regions and } \\
\text { countries }\end{array}$} & \multicolumn{2}{|c|}{ Area with irrigation ( 1,000 hectares) } & \multirow{2}{*}{$\begin{array}{l}\text { Increase from } \\
1960 \text { s to } 2010 \mathrm{~s} \\
(1,000 \text { hectares })\end{array}$} & \multirow[b]{2}{*}{ Increase (\%) } \\
\hline & $1960 \mathrm{~s}$ & 2010s & & \\
\hline LAC & $9,059.9$ & $24,240.3$ & $15,180.4$ & 167.6 \\
\hline Argentina & $1,112.2$ & $2,337.4$ & $1,225.2$ & 110.2 \\
\hline Brazil & 612.2 & $5,400.0$ & $4,787.8$ & 782.0 \\
\hline Mexico & $3,216.7$ & $6,496.0$ & $3,279.3$ & 101.9 \\
\hline Rest of LAC & $4,118.8$ & $10,006.9$ & $5,888.1$ & 143.0 \\
\hline World & $170,668.3$ & $327,245.8$ & $135,898.0$ & 91.7 \\
\hline LAC/world & $5.3 \%$ & $7.4 \%$ & & \\
\hline \multicolumn{5}{|c|}{ Irrigated land as share of total land (\%) } \\
\hline LAC & 1.6 & 3.2 & & \\
\hline World & 3.8 & 6.7 & & \\
\hline
\end{tabular}

Source: Authors' calculations based on FAO (2018).

Note: $L A C=$ Latin America and the Caribbean.

1960 s, it is still only 3.2 percent of the total agricultural area in that region, while 6.7 percent of the world's agricultural area is irrigated.

\section{Farm Size and Land Tenure Issues}

As discussed above, the unequal land structure in LAC, with the traditional dichotomy of "latifundio-minifundio," has been a trait of many LAC countries since the colonial period. Notwithstanding earlier land reforms (many linked to peasants' revolts and revolutions in the first part of the 20th century), the agrarian reforms that took place during the Alliance for Progress in the 1960s and 1970s, and a more recent phase since the return of democracy, inequality of land ownership remains high. At the same time, it should be noted that more recently the greater integration of rural and urban markets, along with the expansion of value chains, and the growth of exports have led to a more diversified land structure and the emergence of a segment of middlesized farms.

Besides the issue of inequality, LAC continues to be the developing region with the largest average landholdings. Table 6.14 shows the average holding size, based on the most recent data compiled by the FAO and analyzed in Lowder, Skoet, and Singh (2014). ${ }^{27}$ The table includes all LAC countries cov-

27 Data correspond to the "2000" column in Table 2 of Lowder, Skoet, and Singh (2014), except for Mexico, Paraguay, Peru, and Honduras; that group corresponds to the "1990" column. 
TABLE 6.14 Average size of agricultural holdings in LAC in comparison with other countries

\begin{tabular}{|c|c|c|c|}
\hline \multicolumn{2}{|c|}{ Latin American countries } & \multicolumn{2}{|c|}{ Non-Latin American countries } \\
\hline Country or region & Area (hectares) & Country or region & Area (hectares) \\
\hline Argentina & 582.5 & Australia & $3,243.2$ \\
\hline Uruguay & 287.4 & Canada & 273.4 \\
\hline Chile & 83.7 & New Zealand & 223.4 \\
\hline Paraguay & 77.5 & United States & 178.4 \\
\hline Brazil & 72.8 & United Kingdom & 70.9 \\
\hline Venezuela & 60.0 & France & 45.0 \\
\hline Mexico & 41.4 & Germany & 40.5 \\
\hline Nicaragua & 31.3 & Spain & 23.9 \\
\hline Colombia & 25.1 & Saudi Arabia & 16.7 \\
\hline Peru & 20.1 & Tunisia & 10.5 \\
\hline Ecuador & 14.7 & Senegal & 4.3 \\
\hline Panama & 11.7 & Thailand & 3.2 \\
\hline Honduras & 11.2 & Myanmar & 2.5 \\
\hline Guatemala & 4.5 & India & 1.3 \\
\hline Trinidad and Tobago & 4.4 & Japan & 1.2 \\
\hline Jamaica & 2.2 & Viet Nam & 0.7 \\
\hline LAC average & 83.2 & World average & 76.7 \\
\hline LAC median & 28.2 & World median & 4.7 \\
\hline
\end{tabular}

Source: Based on data from Lowder, Skoet, and Singh (2014).

Note: $L A C=$ Latin America and the Caribbean.

ered in Lowder, Skoet, and Singh (2014) and, as a comparison, a sample of other countries in the same study.

As noted, another characteristic of landholdings in LAC is the inequality: in the late 1990s and early 2000s, the concentration measured by the Gini coefficient for landholdings in LAC was about 0.82, against 0.53 in Africa, 0.57 in Asia (developing), 0.59 in the European Union, and 0.64 in Canada (Diao et al. 2005). In some countries, such as Brazil, the inequality is large: the data reported in Lowder, Skoet, and Singh (2014) indicate that farms larger than 1,000 hectares represented 1 percent of all units but included 45 percent of the land (with an average size of some 3,200 hectares), while those with less than 2 hectares represented 20 percent of the units but occupied only 0.25 percent of the land (average 0.9 hectares) ${ }^{28}$ This heterogeneity explains

28 It was estimated that 8 percent of farms produced 85 percent of the value of agricultural production (Ribeiro Vieira Filho, Garcia Gasques, and Gervásio de Sousa 2011). 
the relatively intermediate average value for the whole country. In fact, the disparities are so large that a previous government created two separate ministries, one for commercial farms and another for small farmers (IFAD 2016).

During the last decade, the process of concentration may have increased further in several countries, but it has declined in others, such as Mexico (CEPAL, FAO, and IICA 2012). A clear picture will only be available when the latest round of censuses is processed.

Other trends and facts related to land issues include an expansion of land buying in the region, mainly by regional firms and local groups expanding into neighboring countries; the concentration of production (but not land ownership) through schemes to achieve economies of scale, such as "agricultural planting pools" in the Southern Cone; and the expansion of contract farming in most LAC countries (Dirven 2011; CEPAL, FAO, and IICA 2012; FAO 2012). ${ }^{29}$

All in all, data from Lowder, Skoet, and Singh (2014) suggest that there were about 7 million farmers with less than 5 hectares of land, on about 11 million hectares. ${ }^{30}$ In the next bracket there was a variety of intermediate family farms in the range of 5 to 200 hectares, with different levels of assets and market access, amounting to some 5-6 million units with about 210 million hectares. ${ }^{31}$ Finally there were about 500,000 commercial farms with more than 200 hectares per unit, occupying somewhat more than 500 million hectares (Lowder, Skoet, and Singh 2014, annex 6).

Policymaking in LAC has always been complicated by this heterogeneity. Public policies will have to acknowledge this fact and consider differentiated policies by types of producers, possibly defining and implementing adequate public programs in support of small farmers and family farms and monitoring concentration of land and ensuring that "land grabbing" does not take place. While for commercial farms the most important need is to develop an adequate business policy environment (Díaz-Bonilla, Orden, and Kwieciński 2014), for small and family farms public policies should not only eliminate biases against small farmers in land, labor, inputs, and credit markets, but also make sure that value chains operate in ways that allow an adequate integration

29 These agricultural planting pools are financial and operational vehicles managed by agricultural professionals, where different people contribute capital to finance a productive cycle (which may be an annual crop or longer crop and livestock operations). When the cycle finishes, the net profits are distributed among the investors.

30 A more adequate classification than hectares of land would be based not only on size but also on other variables, such as the levels and origins of their incomes (Berdegué and Fuentealba 2011).

31 Berdegué and Fuentealba (2011) estimated a group of family farms to be around 5 million with some 300 million hectares. 
of those producers. Also, more funds for public R\&D in support of family and small farms, diversified crops and livestock activities, and mitigation and adaptation research linked to climate change will be needed.

\section{Transformation of Rural Economies, Rural-Urban Linkages, and Value Chains}

The process of urbanization (discussed in more detail in the first section and Table 6.2; see also Chapter 9), along with the expansion of infrastructure and intermediate cities, and the greater integration of rural and urban markets have led to important changes in rural labor markets and nonagricultural rural activities, as well as the expansion of and greater complexity in value chains, domestically and for exports.

Regarding rural labor markets, Reardon, Berdegué, and Escobar (2001) summarize the evidence of 11 country studies in LAC by the late 1990 s and early 2000s, noting that rural nonfarm employment (RNFE) and rural nonfarm incomes (RNFI) have grown significantly during the past three decades, with RNFI averaging 40 percent of total rural incomes in the countries analyzed. Reardon, Berdegué, and Escobar (2001) also observe, in terms of shares of rural incomes, "(1) nonfarm wage incomes exceed self-employment incomes; (2) RNFI far exceeds farm wage incomes; (3) local RNFI far exceeds migration incomes; (4) service-sector RNFI far exceeds manufactures RNFI." Their conclusion is "the need for more development program attention to wage employment in the service sector, versus the traditional focus on small enterprise manufactures." They mention that although there are other new development engines in rural areas (such as tourism, mining, and forestry), agricultural production maintains its crucial importance as an economic anchor in rural areas.

Related work by CEPAL, FAO, and IICA (2012) and IFAD (2016) confirmed and expanded evidence regarding several of those trends, including the increase in nonagricultural rural activities, with a larger presence of women's employment and growth in urban residence among agricultural workers (CEPAL, FAO, and IICA 2012). The latter trend has been helped by better rural infrastructure: for instance, the level of rural electrification in LAC has reached 88 percent of the population (against 71 percent for all developing countries and 73 percent for the world as a whole), while the number of mobile phone subscriptions in LAC is above the average for developing countries and the world (World Bank 2018).

Value chains have also been significantly modified by different waves of changes in the processing and retail segments (see Chapter 12). The larger 
South American countries, which were more advanced in their development and urbanization, saw a surge of foreign direct investment (FDI) in the processing sector in the mid-1980s to early 1990s (after the process of liberalization and privatization of those years), while retail transformation started in the early 1990s. Mexico and Central America followed later, with retail transformation starting only in the middle to late 1990s (Reardon and Timmer 2012).

In the processing sector, in addition to the traditional milling and meat-packing industries, there has been a more recent advance of large conglomerates, particularly in beef, poultry, and pork production. The expansion of FDI related to processed and packaged products has been transforming several value chains (Bolling and Gehlhar 2005). On the input side, international seed companies and other providers have expanded in the region, providing technology mainly for cereals and oilseeds. Machinery and irrigation companies have also extended their operations in the region.

On the retail side, the most important change has been the supermarkets restructuring whole food chains, including both processed and fresh products (Reardon and Timmer 2012). In LAC the expansion of supermarkets started earlier and has proceeded further than in other developing regions: in the 1990 s, retail was dominated by domestic firms, with supermarkets covering about 10-20 percent of national food retail sales, but by 2000 supermarkets had increased their share to 50-60 percent and, in many countries, have lately been penetrating national food retail at rates that took several decades to achieve in the United States. Brazil has the highest share of supermarkets, followed by Argentina, Chile, Costa Rica, Colombia, and Mexico. The advance of supermarkets was faster in processed, dry, and packaged foods but has also been increasing in fresh products, including vegetables, fruits, and different types of meats. Still, the share of supermarkets in fresh foods was estimated to be about half their share in packaged foods (Reardon and Berdegué 2002). But supermarkets in Latin America buy about 2.5 times more of some fresh products, such as fruits and vegetables, from local producers than are exported to world markets (Reardon and Berdegué 2002). It has also been noted that the expansion of supermarkets has been driven by FDI, and according to some estimates in LAC, multinational chains constitute about 70-80 percent of the top five chains in several countries (Reardon and Berdegué 2002).

A related debate has been about whether small and family farms may benefit from the advance of supermarkets and from integrating in value chains such as those for fruits and vegetables. Several studies (see Chapter 11) suggest 
that small farmers (and not just large farmers) sell to supermarket chains because the chains use a combination of specialized wholesalers and traditional wholesale markets; those small farmers with the assets or investments needed for consistent and quality supply (irrigation, road access, and education) tend to benefit more (see also Michelson 2013 for Nicaragua); and the farmers selling to supermarkets report moderate to substantial gains in incomes compared with nonparticipants (although at times the gain may not be higher prices but risk reduction). ${ }^{32}$

\section{Concluding Remarks}

Although, as noted, LAC is a heterogeneous region, it still has enough internal similarities in its geography and history to present a clear contrast with other developing regions considered in this book.

First, the pattern of occupation during colonial times and the integration with the world economy has defined the unequal structure of land ownership and the evolution of the agriculture sector in LAC. World markets and global developments, instead of domestic markets, have a stronger impact on agricultural developments. Changes in production took place within agrarian structures showing large inequalities in land tenure, with small farms fragmenting further and large landholdings expanding, which at times put pressure on land owned by family farms and local communities. There have also been important developments in rural labor markets, with more salaried employment, the expansion of nonagricultural rural activities, and a differentiated role for women's labor. The combination of high inequality and strong outward orientation is peculiar to LAC.

Second, LAC has seen greater experimentation with, and changes of, economic and social policies. The policies of supporting import substitution industrialization after WWII were later reversed, and now the region is following macro, trade, and agricultural policies that in many countries may have shifted toward greater support for the agriculture sector. Regarding social policies, LAC pioneered conditional cash transfers that helped reduce poverty and inequality (but see below).

32 And additional debate relates to whether increased globalization of value chains may raise prices of specialty food products and have negative welfare effects at the household level in some countries, as it has been argued in the case of quinoa in Peru. However, regarding this particular product, Bellemare, Fajardo-Gonzalez, and Gitter (2018) do not find evidence of harmful effects on local households, and rather the opposite seems to be true. 
Third, with regard to socioeconomic conditions, LAC experienced improvements in income per capita and education and health indicators, along with declines in poverty rates, which places LAC at clearly better levels than the average for Asian and African developing countries. The incidence of poverty in rural areas is larger than in the cities, but because LAC countries have become the most urbanized in the world (another difference from other regions), the greatest concentration of poverty occurs in urban centers in the region. Indigenous populations and Afro-descendants are still among the poorest groups in the society. At the same time, LAC shows some of the highest levels of inequality in the world, which starts with large inequalities in land tenure and wealth in general.

Fourth, LAC has moved further along than other developing regions in the nutrition transition. Undernourishment has declined significantly, but in some cases the lack of micronutrients is still important. Furthermore, the large economic and social costs associated with the diet-related health problem of growing overweight and obesity rates constitute some of the most significant food policy challenges ahead for the region.

Fifth, value chains have also evolved significantly, with increased urbanization and a larger presence of intermediate cities and with agricultural and agro-industrial activities increasingly controlled by large agricultural operators, input companies, agro-industrial processors, and supermarket chains. In general, agricultural markets are more modernized and integrated in LAC than in other developing regions.

Sixth, LAC's agriculture sector has had relatively strong performance during the last five to six decades, outpacing global growth in food availability, while agricultural production increased its share of global output from about 10 percent in the 1960 s to about 13 percent in the 2010s. This increase resulted to a large extent from agricultural expansion in Brazil. During the 2000s, LAC also became the world's main net food-exporting region, supported mainly by the net trade surpluses generated by Brazil and Argentina. Policy changes related to macroeconomic stabilization and liberalization led to a significant diversification of agricultural production, which has been reflected in important changes in the structure of exports: the share of traditional products (such as coffee, cocoa, sugar, and textiles) in total exports declined, while that of fruits and vegetables, oilseeds, and meat products increased.

Seventh, those gains in LAC's agriculture have been driven in part by productivity improvement but also resulted from a significant expansion of agricultural area over the last half century. This is another differential 
characteristic of LAC: the region has contributed to a third of the global increase in agricultural land (crops and pastures) since the 1960s and also accounted for some 80 percent of global deforestation from 1990 to 2015, which has resulted in land-use change contributing more to LAC's greenhouse gas (GHG) emissions than any other source. Another worrisome consequence of rapid land-use change is the pressure on LAC's globally important reservoirs of biodiversity. A similarly fast-paced expansion of LAC's agricultural area will be difficult to repeat in the future without affecting climate change and biodiversity.

The combination of the previous two points is another crucial difference between LAC and other regions, developing or developed: the region's performance has important global implications because of the dual role it plays by contributing both to the world's food security (as the main net food exporter region) and to environmental sustainability at the national and global levels (as the main provider of a variety of environmental public goods such as carbon sinks, oxygen, and biodiversity). Over the long term, sustaining LAC's dual role will require substantial investment in agricultural R\&D, infrastructure, and governance of natural resources (Díaz-Bonilla et al. 2014). Failure to take adequate measures regarding efficiency, productivity, and sustainability will have far-reaching implications for the world if LAC cannot continue performing its double global functions in support of food security and environmental public goods.

Public investment in agricultural R\&D has increased somewhat, particularly over the last decade. But LAC's average ratios are well below the levels of developed nations, and a few countries, notably Brazil, account for much of the improvements, as investment has declined in the smaller and poorer countries that are most in need of agricultural R\&D.

This review tried to highlight the complex challenges for LAC countries regarding their agricultural and rural development. Powerful socioeconomic drivers could keep this region and the world on a business-as-usual path that appears unsustainable. Reshaping those trends requires multiple interventions that include but go beyond the agricultural sector. Governments need to take a broader agrifood systems approach to attain the desired objectives related to growth, employment, poverty and inequality alleviation, health and nutrition, and environmental sustainability, acknowledging trade-offs and strengthening $\mathrm{R} \& \mathrm{D}$, innovation, and knowledge activities.

If LAC countries fail to address those challenges, not only will the region suffer, but the negative consequences will be felt globally. 


\section{References}

Adato, M., and J. Hoddinott, eds. 2010. Conditional Cash Transfers in Latin America. Baltimore: Johns Hopkins University Press.

AgIncentives. 2020. AgIncentives database facilitated by IFPRI. http://www.ag-incentives.org/.

Anderson, K., and S. Nelgen. 2013. Updated National and Global Estimates of Distortions to Agricultural Incentives, 1955 to 2011. Washington, DC: World Bank.

ASTI. 2017. ASTI database facilitated by IFPRI. https://www.asti.cgiar.org/.

Balassa, B., and Associates. 1971. The Structure of Protection in Developing Countries. Baltimore: Johns Hopkins University Press.

Beintema, N., A. Nin-Pratt, and G.-J. Stads. 2020. "Global Agricultural Research Investments: Key Trends.”. ASTI Program Note. Washington, DC: IFPRI.

Beintema, N., G. Stads, K. Fuglie, and P. Heisey. 2012. ASTI Global Assessment of Agricultural RઐD Spending. Washington, DC: IFPRI, ASTI, and Global Forum on Agricultural Research.

Bellemare, M. F., J. Fajardo-Gonzalez, and S. R. Gitter. 2018. “Foods and Fads: The Welfare Impacts of Rising Quinoa Prices in Peru." World Development 112: 163-179.

Berdegué, J. A., and R. Fuentealba. 2011. "Latin America: The State of Smallholders in Agriculture." In Conference on New Directions for Smallholder Agriculture, 24-25 January 2011, Rome. Rome: International Fund for Agricultural Development.

Berdegué, J. A., and F. J. Proctor with C. Cazzuffi. 2014. Inclusive Rural-Urban Linkages. Working Paper Series 123. Working Group: Development with Territorial Cohesion. Territorial Cohesion for Development Program. Santiago, Chile: Latin American Center for Rural Development (Rimisp).

Bolling, C., and M. Gehlhar. 2005. Global Food Manufacturing Reorients to Meet New Demands. Agriculture Information Bulletin Number 794. Washington, DC: USDA/Economic Research Service.

Bustos, P., B. Caprettini, and J. Ponticelli. 2016. "Agricultural Productivity and Structural Transformation: Evidence from Brazil." American Economic Review 106 (6): 1320-1365.

Byerlee, D., and R. Echeverría, eds. 2002. Agricultural Research Policy in an Era of Privatization. Wallingford, UK: CABI.

CEPAL (United Nations Economic Commission for Latin America and the Caribbean), FAO (Food and Agriculture Organization of the United Nations), and IICA (InterAmerican Institute for Cooperation on Agriculture). 2012. Perspectivas de la agriculturay del desarrollo rural en las Américas: una mirada hacia América Latina y el Caribe. Santiago, Chile: FAO. 
Committee on a New Biology for the 21st Century. 2009. A New Biology for the 21st Century. Ensuring the United States Leads the Coming Biology Revolution. National Research Council. Washington, DC: National Academies Press.

Development Initiatives. 2018. 2018 Global Nutrition Report: Shining a Light to Spur Action on Nutrition. Bristol, UK: Development Initiatives.

Diao, X., E. Diaz-Bonilla, S. Robinson, and D. Orden. 2005. Tell Me Where It Hurts, An' I'll Tell You Who to Call: Industrialized Countries' Agricultural Policies and Developing Countries. MTID Discussion Paper 84. Washington, DC: IFPRI.

Díaz-Bonilla, E. 2015. Macroeconomics, Agriculture, and Food Security: A Guide to Policy Analysis in Developing Countries. Washington, DC: IFPRI.

Díaz-Bonilla, E., D. Orden, and A. Kwieciński. 2014. Enabling Environment for Agricultural Growth and Competitiveness: Evaluation, Indicators and Indices. OECD Food, Agriculture and Fisheries Paper 67. Organisation for Economic Co-operation and Development.

Díaz-Bonilla, E., E. Saini, G. Henry, B. Creamer, and E. Trigo. 2014. Global Strategic Trends and Agricultural Research and Development in Latin America and the Caribbean: A Framework for Analysis. CIAT Publication 400. Cali, Colombia: Centro Internacional de Agricultura Tropical.

Díaz-Bonilla, E., and M. Torero. 2016. "Regional Developments: Latin America and Caribbean.” In 2016 Global Food Policy Report, 104-107. Washington, DC: IFPRI.

Dirven, M. 2011. Dinámicas del mercado de tierras en los paises del Mercosur y Chile: una mirada analitica-critica. 2011. Document prepared at the request of the FAO Regional Office for Latin America and the Caribbean for presentation at the workshop "Dinámicas en el mercado de la tierra en América Latina." November 14-15. Santiago, Chile: FAO.

Echeverría, R., E. Trigo, and D. Byerlee. 1996. Institutional Change and Effective Financing of Agricultural Research in Latin America: Findings of a Workshop Organized by the InterAmerican Development Bank and the World Bank in August 1995. World Bank Technical Paper 330. Washington, DC: World Bank.

Engerman, S., and K. Sokoloff. 2002. Factor Endowments, Inequality, and Paths of Development among New World Economies. NBER Working Paper 9259. Cambridge, MA: National Bureau of Economic Research.

Fan, S., ed. 2008. Public Expenditures, Growth, and Poverty: Lessons from Developing Countries. Washington, DC: IFPRI.

FAO (Food and Agriculture Organization of the United Nations). 2012. Dinámicas del mercado de la tierra en América Latina y el Caribe: concentración y extranjerización. Santiago, Chile: Editores Fernando Soto Baquero y Sergio Gómez. 
Fuglie, K. O. 2012. "Productivity Growth and Technology Capital in the Global Agricultural Economy." In Productivity Growth in Agriculture: An International Perspective, edited by K. Fuglie, S. L. Wang, and V. E. Ball, 335-368. Wallingford, UK: CABI.

- 2015. "Accounting for Growth in Global Agriculture." Bio-based and Applied Economics 4 (3): $221-254$.

Hayami, Y., and V. W. Ruttan. 1985. Agricultural Development: An International Perspective (revised and expanded). Baltimore: Johns Hopkins University Press.

HLPE (High Level Panel of Experts). 2017. Nutrition and Food Systems. A Report by the High Level Panel of Experts on Food Security and Nutrition. Rome.

IFAD (International Fund for Agricultural Development). 2016. Rural Development Report 2016: Fostering Inclusive Rural Transformation. Rome.

IFPRI (International Food Policy Research Institute). 2019. "Agricultural Total Factor Productivity (TFP), 1991-2015: 2019 Global Food Policy Report Annex Table 4.” https:// dataverse.harvard.edu/dataset.xhtml?persistentId=doi:10.7910/DVN/9IOAKR.

ISAAA (International Service for the Acquisition of Agri-biotech Applications). 2017. Global Status of Commercialized Biotech/GM Crops: 2017. ISAAA Brief 53. Ithaca, NY.

Kawagoe, T., K. Otsuka, and Y. Hayami. 1986. "Induced Bias of Technical Change in Agriculture: The United States and Japan, 1880-1980." Journal of Political Economy 94 (3 Pt. 1): 523-544.

Little, I., T. Scitovsky, and M. Scott. 1970. Industry and Trade in Some Developing Countries. Paris: Oxford University Press.

Lowder, S. K., J. Skoet, and S. Singh. 2014. "What Do We Really Know about the Number and Distribution of Farms and Family Farms Worldwide?” Background paper for The State of Food and Agriculture 2014. ESA Working Paper 14-02. Rome: FAO.

Michelson, H. 2013. "Small Farmers, NGOs and a Walmart World: Welfare Effects of Supermarkets Operating in Nicaragua." American Journal of Agricultural Economics 95 (3): 628-649.

MIT (Massachusetts Institute of Technology). 2011. The Third Revolution: The Convergence of the Life Sciences, Physical Sciences and Engineering. Washington, DC: MIT.

Nin-Pratt, A., C. Falconi, C. E. Ludena, and P. Martel. 2015. Productivity and the Performance of Agriculture in Latin America and the Caribbean: From the Lost Decade to the Commodity Boom. IDB Working Paper Series N.608. Washington, DC: Inter-American Development Bank. 
Pardey, P. G. 2012. "Foresight in LAC Agriculture: Agricultural Technology \& Intellectual Property." Paper presented at the Workshop on Future Challenges and Opportunities for Latin America and the Caribbean, IADB-CIAT, March 2012.

Pardey, P., and N. Beintema. 2001. Slow Magic: Agricultural R\&D a Century after Mendel. Food Policy Report. October 26, 2001. Washington, DC: IFPRI.

PIADAL (Panel Independiente sobre la Agricultura para el Desarrollo de América Latina). 2013. Agricultura y Desarrollo en América Latina: Gobernanza y Políticas Públicas. Buenos Aires: Editorial Teseo.

Pinstrup-Andersen, P. 2011. The Food System and Its Interaction with Human Health and Nutrition. IFPRI 2020 Conference Brief 13. Washington, DC: IFPRI.

Popkin, B. M., and T. Reardon. 2018. Obesity and the Food System Transformation in Latin America. Obesity Reviews. Hoboken, NJ, US: John Wiley \& Sons on behalf of World Obesity Federation.

Prebisch, R. 1950. The Economic Development of Latin America and Its Principal Problems. New York: United Nations.

- 1968. "Development Problems of the Peripheral Countries and the Terms of Trade." In Economics of Trade and Development, edited by J. D. Theberge. New York: John Wiley and Sons.

Reardon, T., and J. A. Berdegué. 2002. "The Rapid Rise of Supermarkets in Latin America: Challenges and Opportunities for Development." Development Policy Review 20 (4): 371-388.

Reardon, T., J. A. Berdegué, and G. Escobar. 2001. "Rural Nonfarm Employment and Incomes in Latin America: Overview and Policy Implications." World Development 29 (3): 395-409.

Reardon, T., R. Echeverría, J. Berdegué, B. Minten, S. Liverpool-Tasie, D. Tschirley, and D. Zilberman. 2019. "Rapid Transformation of Food Systems in Developing Regions: Implications for Agricultural Research Strategies." In "Agricultural Research for Rural Prosperity: Rethinking the Pathways," edited by T. Tomich, P. Lidder, and P. Carberry. Special issue, Agricultural Systems 172 (Feb.): 47-59.

Reardon, T., and P. Timmer. 2012. "The Economics of the Food System Revolution." Annual Review of Resource Economics 4: 14.1-14.40.

Ribeiro Vieira Filho, J., J. Garcia Gasques, and A. Gervásio de Sousa. 2011. Agricultura e crescimento: cenários e proję̧ôes. IPEA. 1642. Texto para Discussao. Brasilia: Institute of Applied Economic Research.

Singer, H. 1950. "The Distribution of Gains between Investing and Borrowing Countries." American Economic Review 40: 473-485. 
Stads, G. J., N. Beintema, S. Perez, K. Flaherty, and C. Falconi. 2016. Agricultural Research in Latin America and the Caribbean: A Cross-Country Analysis of Institutions, Investment, and Capacities. ASTI-IDB Document. Washington, DC: IFPRI.

Trigo, E. 2012. “Los Nuevos Escenarios para la Institucionalidad de la Investigación Agroalimentaria en América Latina y el Caribe. Borrador." Draft prepared for the Inter-American Development Bank, Buenos Aires.

von Grebmer, K., J. Bernstein, D. Nabarro et al. 2016. 2016 Global Hunger Index: Getting to Zero Hunger. Bonn, Washington, DC, and Dublin: Welthungerhilfe, IFPRI, and Concern Worldwide.

World Bank. 1986. World Development Report 1986. New York: Oxford University Press.

— 2014. The State of Social Safety Nets 2014. Washington, DC: World Bank.

- 2018. World Development Indicators database. Accessed at various times in 2018. https:// databank.worldbank.org/reports.aspx?source=world-development-indicators\#. 